\section{Retinal nerve fiber layer, ganglion cell complex, and choroidal thicknesses in migraine}

\section{Espessuras da camada de fibras nervosas, do complexo de células ganglionares e da coroide na migrânea}

\section{Dear Editor,}

We have read and reviewed the article titled "Retinal nerve fiber layer, ganglion cell complex, and choroidal thicknesses in migraine" by Çolak et al., with great interest ${ }^{(1)}$. The authors investigated 45 migraine patients with aura and peripapillary retinal nerve fiber layer (RNFL), ganglion cell complex, and choroid thicknesses using optical coherence tomography. They found that RNFL was significantly thinner in the superior and inferior quadrants in the migraine group when compared with that in the control group. Çolak et al. demonstrated that the subfoveal, temporal, and nasal choroidal thickness (CT) at 500, 1000, and $1500 \mu \mathrm{m}$, respectively, were significantly thinner in the migraine group as compared with those in the control group. We express our gratitude to the authors regarding this study. However, we would like to ask Çolak et al. to clarify some important points that might affect CT measurements ${ }^{(1)}$.

The choroid is one of the most vascularized regions of the human body. Therefore, any local, systemic, or environmental factor that affects the vascular tract may have significant influences on CT. For instance, menstrual cycle and pregnancy may significantly affect $\mathrm{CT}^{(2)}$. The paper indicated that the mean age of the 45 participants was $36.1 \pm 6.5$ years (ranging between 20 and 45 years), and 37 of them were female. Ulaş et al. showed that CT decreased by $6.47 \%$ between early follicular and mid-luteal phases and by $2.64 \%$ between early follicular and ovulatory phases ${ }^{(3)}$. Although the effect of pregnancy on CT has been debated in the literature, some studies have demonstrated significantly increased CT during pregnancy, particularly during the second trimester ${ }^{(2)}$. Accordingly, we would like to ask the authors whether they considered the menstrual cycle and pregnancy status of the female participants. Additionally, we suggest that smoking, alcohol consumption, drinking caffeinated beverages, body mass index, systemic blood pressure, and environmental lighting conditions, which significantly affect $C T$, should be addressed in the paper.

Finally, we suggest that the duration of the disease, frequency of migraine episodes, and the time passed after the latest episode as well as its severity may significantly affect the results, primarily $C T$, in migraine patients with aura. We are curious about the authors' opinions on the aforementioned concerns.

Salih Uzun ${ }^{1}$ Emre Pehlivan²

Submitted for publication: June 1,2016 Accepted for publication: June 1,2016

1 Department of Ophthalmology, Etimesgut Military Hospital, Ankara, Turkey. 2 Department of Ophthalmology, Eskisehir Military Hospital, Eskisehir, Turkey.

Funding: No specific financial support was available for this study.

Disclosure of potential conflicts of interest: None of the authors have any potential conflict of interest to disclose.

Corresponding author: Salih Uzun. Etimesgut Asker Hastanesi Goz Hastaliklari Servisi. Etimesgut-Ankara, 06790 - Turkey - E-mail: s.uzun84@gmail.com

\section{REFERENCES}

1. Colak HN, Kantarc FA, Tatar MG, Eryilmaz M, Uslu H, Goker H, et al. Retinal nerve fiber layer, ganglion cell complex, and choroidal thicknesses in migraine. Arq Bras Oftalmol. 2016;79(2):78-81.

2. Tan KA, Gupta P, Agarwal A, Chhablani J, Cheng CY, Keane PA, et al. State of science: Choroidal thickness and systemic health. Surv Ophthalmol. 2016;S0039-6252:30010-2.

3. Ulaş F, Doğan U, Duran B, Keleş A, Ağca S, Celebi S. Choroidal thickness changes during the menstrual cycle. Curr Eye Res. 2013;38(11):1172-81. 